\title{
SCREENING OF TOXIC CORALS AND ISOLATION OF A TOXIC POLYPEPTIDE FROM GONIOPORA SPP
}

$\operatorname{AUTHOR}(\mathrm{S})$ :

Hashimoto, Yoshiro; Ashida, Katsuro

CITATION:

Hashimoto, Yoshiro ... [et al]. SCREENING OF TOXIC CORALS AND ISOLATION OF A TOXIC POLYPEPTIDE FROM GONIOPORA SPP. PUBLICATIONS OF THE SETO MARINE BIOLOGICAL LABORATORY 1973, 20: 703-711

\section{ISSUE DATE:}

1973-12-19

URL:

http://hdl.handle.net/2433/175749

RIGHT: 


\title{
SCREENING OF TOXIIC CORALS AND ISOLATION OF A TOXIC POLYPEPTIDE FROM GONIOPORA SPP. ${ }^{1)}$
}

\author{
Yoshiro HASHIMOTO and KatSURo ASHIDA \\ Laboratory of Marine Biochemistry, Faculty of Agriculture \\ The University of Tokyo, Tokyo, Japan
}

With 3 Text-figures

\section{Introduction}

Many species of coral feeders are included among ciguatoxic fishes (HALSTEAD, 1967) and there has been an assumption that toxins which have been observed in these coral feeders might originate from the toxic corals on which they feed (HALSTEAD, 1967; НАSнімото et al., 1969). In order to search for a possible origin of the toxin found in coral feeders, we screened toxic corals by extracting the specimens with hot $70 \%$ ethanol and by injecting the resulting extract into mice. We found 20 toxic specimens belonging to 8 species among 104 specimens collected at Ishigaki Island. Among them, Goniopora spp. were found to contain a toxic substance that induced characteristic symptoms in mice: hypersensitivity, stiffness of the entire body and marked cyanosis. Since this appeared to be a new marine toxin, we attempted its isolation and characterization.

This paper deals with the screening for toxic corals and with the isolation of Goniopora toxin, together with its chemical and pharmacological properties.

\section{Materials and Methods}

A total of 104 specimens were collected for screening at Ishigaki Island in May 1968. The soft parts were shaved off in the field with a knife and transported frozen by air to our laboratory, where they were kept at $-20^{\circ} \mathrm{C}$ until used. The specimens belonging to 29 genera were identified by Dr. K. YAMAZATO, University of the Ryukyus.

Specimens of the stony corals Goniopora spp. were mainly collected in tide pools of coral reefs in the Ryukyu Islands. The soft parts as mentioned above were retained, corresponding in wet weight to approximately $25 \%$ of the whole mass of coral and containing approximately $30 \%$ of the calcified tissues. In order to check seasonal, geographical and individual variations in toxicity, 60 specimens were collected during

1) Studies on Marine Toxins-XXXVI. 
1969 to 1971 between April and October, at Okinawa Island, Amami Islands, and Shirahama. For isolation of the toxin, a quantity of soft parts, weighing about $10 \mathrm{~kg}$, was collected in July 1971 at Amami-Oshima Island.

Screening Test for Toxic Corals: A $10 \mathrm{~g}$ portion of each minced specimen was extracted with hot $70 \%$ ethanol; fat-soluble and water-soluble fractions were obtained by the method that we have used for ciguatoxic fishes (HАsнimoto et al., 1969). The water-soluble fraction was dissolved in $10 \mathrm{ml}$ of distilled water and the fat-soluble one in $2 \mathrm{ml}$ of $0.8 \%$ Tween 60 solution. Two mice, weighing $20 \pm 2 \mathrm{~g}$, were injected i.p. with a $1-\mathrm{ml}$ portion each. The mice were observed for 3 days after injection. When one of a pair of mice died, a third mouse was injected. A specimen was regarded as toxic, if two out of three mice were killed.

Assay Method for Goniopora Toxin: Frozen coral, usually weighing $10 \mathrm{~g}$, was ground in a mortar with an equal volume of aqueous $0.9 \% \mathrm{NaCl}$, sonicated at $20 \mathrm{kc}$ per sec for $20 \mathrm{~min}$, and centrifuged at $10,000 \mathrm{rpm}$ for $15 \mathrm{~min}$. The supernatant was filtered and used as the original test solution for the toxicity test. The amount of toxin was determined by the dose-time-to-death curve, as described by MCFARREN (1966). A $1-\mathrm{ml}$ portion was injected i.p. into mice weighing $20 \pm 2$ g. From the dilution necessary to kill 2 mice within a range of 30 to $60 \mathrm{~min}$ and from the mean death time at that dilution, the amount of toxin was determined from the dose-response curve shown in Fig. 1. In the Figure, the amount of toxin is expressed as mouse units (MU); one mouse unit is defined as the minimum quantity of toxin required to kill a $20 \mathrm{~g}$ mouse. Toxicity of the coral specimens was indicated by MU per $\mathrm{ml}$ of the original test solution and toxicity of preparations by the minimum lethal dose in $\mathrm{mg}$ per $\mathrm{kg}$ of mouse or MU per ml. This assay method was also used for monitoring the elution of the toxin in column chromatography.

Assay Method for Hemolytic Activity: Hemolytic activity was determined by using a $2 \%$ rabbit blood cell suspension, as done routinely in our laboratory (HASHIMOTO and Oshima, 1972) and was expressed by a saponin unit (SU).

Dose-Response Curve in Mice: The dose-time-to-death curve was determined after the method of KonOsu et al. (1968). Two different preparations were used: one was a crude saline extract with a lethality of $300 \mathrm{mg}$ per $\mathrm{kg}$ mouse, and the other a purified preparation having a lethality of $0.5 \mathrm{mg}$ per $\mathrm{kg}$ mouse.

Purification of Goniopora Toxin: After preliminary tests the following procedure was established. One kilogram of raw material was ground with an equal volume of aqueous $0.9 \% \mathrm{NaCl}$ in a mortar, sonicated at $20 \mathrm{kc}$ per sec for $20 \mathrm{~min}$, and centrifuged at $10,000 \mathrm{rpm}$, after the $\mathrm{pH}$ of the solution was adjusted to 5.5 with $0.5 \mathrm{~N} \mathrm{HCl}$. The supernatant was filtered and diluted with twice its volume of distilled water prior to chromatography on a column $(6 \times 50 \mathrm{~cm})$ of CM-cellulose (Brown). The CMcellulose had previously been washed thoroughly with $0.5 \% \mathrm{NaCl}$ solution. The column was washed with $0.5 \% \mathrm{NaCl}$ solution and the toxin was then eluted from the column with $2.0 \% \mathrm{NaCl}$ solution. Effluents were collected in $20 \mathrm{ml}$ portions with a 
fraction collector. The toxic fractions were combined, concentrated below $30^{\circ} \mathrm{C}$, and dialyzed against $0.9 \% \mathrm{NaCl}$ solution in a cellophane membrane. The retentate was filtered and passed through a column $(6 \times 50 \mathrm{~cm})$ of Sephadex G-50 (Fine). The toxin was eluted from the Sephadex column with $0.9 \% \mathrm{NaCl}$ solution, and the entire step was repeated. The toxic fractions thus obtained were again concentrated, desalted by dialysis against distilled water and placed on a column $(2.5 \times 95 \mathrm{~cm})$ of Sephadex G-50 (Fine). The toxin was then eluted with distilled water. The elution pattern was monitored by mouse bioassay and by absorption at $280 \mathrm{~nm}$.

Thin Layer Chromatography: Among many supporting media and solvent systems tested, only a combination of Avicel SF (FCM Co.) with 1-butanol-acetic acid- $\mathrm{H}_{2} \mathrm{O}$ $(2: 1: 2)$ was found satisfactory. Spots were visualized with ninhydrin and Dragendorff reagents. In addition, the band was scraped off from the plate, extracted with $0.9 \%$ $\mathrm{NaCl}$ solution, and tested for toxicity.

Ultracentrifugal Analysis: Sedimentation analysis was carried out at $20^{\circ} \mathrm{C}$ on a Hitachi Model UT-1A ultracentrifuge equipped with a synthetic boundary cell at $60,000 \mathrm{rpm}$. The most highly purified test solution was dialyzed against $0.2 \mathrm{M} \mathrm{NaCl}$ solution prior to ultracentrifugation. The same solution was subjected to the approach-to-equilibrium sedimentation method of ARCHIBald (SCHANCHMan, 1959) in a cell described by YPHANTIS (1960).

\section{Results}

Screening of Toxic Corals: The water-soluble fraction was found to be toxic in 20 out of 104 specimens, but none of the fat-soluble fractions were toxic. Toxic corals and observed symptoms in mice are listed in Table 1. Both Goniopora sp. (No. 1) and Palythoa tuberculosa (Nos. 47-49) killed mice in a short time and induced characteristic symptoms. The other toxic corals killed mice very slowly without inducing any remarkable symptoms, except loss of activity. Although Millepora sp. (No. 30) did not kill mice and was considered nontoxic, it evoked remarkable symptoms, such as loss of activity, dyspnea, paralysis of the entire body, jumping, and rapid recovery.

Response of Mice to Goniopora Toxin: Symptoms in mice consisted of hypersensitivity, paralysis of hind limbs, diarrhea, stiffness of the entire body, dyspnea with cyanosis, and death. Contraction of capillary vessels and stiffness of the entire body before death were especially noticeable. The relationship between dose and time-to-death is shown in Fig. 1. It will be noted that identical dose-response curves were obtained for two preparations differing in activity by a factor of 600 . At the minimum lethal dose, mice died within one day.

Toxicity of Goniopora Specimens: Toxicity of 60 specimens ranged from 8 to $64 \mathrm{MU}$ per $\mathrm{ml}$ of the original test solution. Seasonal, geographical and individual variations in toxicity were insignificant.

Purification of Goniopora Toxin: In a typical run, a saline extract with a lethality 
Table 1. Toxic corals from Ishigaki Island.

\begin{tabular}{|c|c|c|c|}
\hline Species & Sample No. & $\begin{array}{l}\text { Average death } \\
\text { time (min) }\end{array}$ & Symptoms in mice \\
\hline Goniopora sp. & 1 & 49 & $\begin{array}{l}\text { Diarrhea, paralysis } \\
\text { of hind limbs, } \\
\text { hypersensitivity, } \\
\text { stiffness of the } \\
\text { entire body, dyspnea } \\
\text { with cyanosis and death }\end{array}$ \\
\hline Coeloseris mayeri VAUGHAN & 33 & 780 & Loss of activity, and death \\
\hline Clavularia sp. & 46 & 960 & $"$ \\
\hline Palythoa tuberculosa & 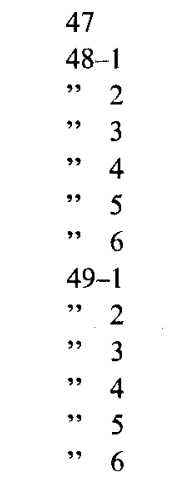 & $\begin{array}{r}65 \\
3 \\
110 \\
105 \\
9 \\
22 \\
3 \\
238 \\
20 \\
41 \\
122 \\
75 \\
5\end{array}$ & $\begin{array}{l}\text { Loss of activity, } \\
\text { paralysis of hind } \\
\text { limbs, dyspnea, } \\
\text { jumping, and death }\end{array}$ \\
\hline Acropora sp. & 66 & 1800 & Loss of activity, and death \\
\hline $\begin{array}{l}\text { Cyphastrea sp. } \\
\text { cf. C. chalcidicum } \\
\text { (ForSKÁL) }\end{array}$ & 69 & 1800 & $"$ \\
\hline Unidentified & 85 & 1740 & , \\
\hline $\begin{array}{l}\text { Pavona (Polyastra) } \\
\text { ebtusata (QUELCH) }\end{array}$ & 90 & 480 & $"$ \\
\hline
\end{tabular}

of $300 \mathrm{mg}$ per $\mathrm{kg}$ mouse was obtained. The toxic fraction from a CM-cellulose column had an estimated lethality of $180 \mathrm{mg}$ per $\mathrm{kg}$; the estimate is based on the observed weight of a fraction residue and the calculated amount of sodium chloride in a residue. Recovery of toxicity was $70 \%$. The most purified toxin that was obtained by Sephadex G-50 column chromatography had a lethality of $0.5 \mathrm{mg}$ per $\mathrm{kg}$. Recovery of activity for the entire purification sequence was $65 \%$. As shown in Fig. 2 , the elution curves from the Sephadex G-50 column, checked by optical density at $280 \mathrm{~nm}$ and lethality to mice, show only single and identical peaks. The hemolytic activity was $0.11 \mathrm{SU}$ in the saline extract and $0.19 \mathrm{SU}$ per $\mathrm{mg}$ of solid in the toxic fraction from a CM-cellulose column. The hemolytic factor was separated from the toxin that is lethal to mice by Sephadex G-50 column chromatography. This factor is now under investigation. 


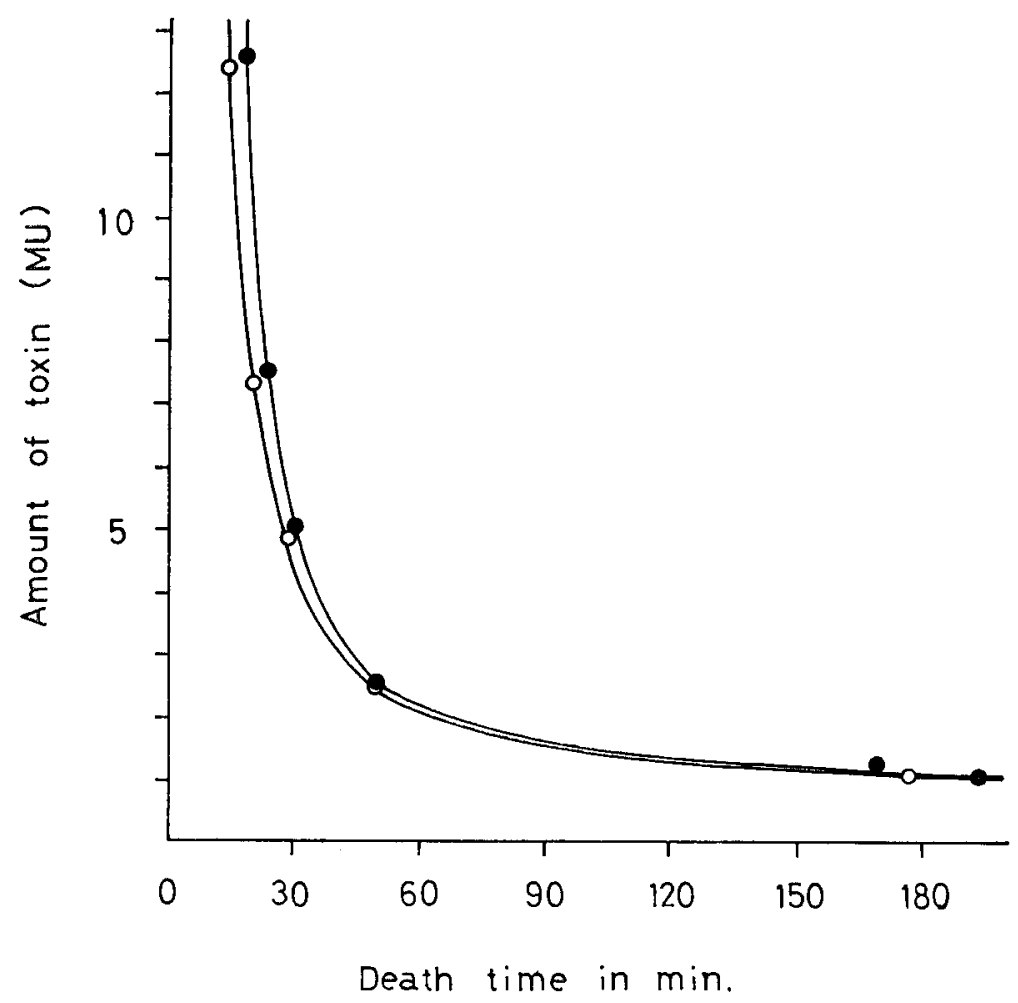

Fig. 1. Dose-response curve for Goniopora toxin.

Crude toxin (300 mg per kg mouse); $\bigcirc — \bigcirc$ Purified toxin $(0.5 \mathrm{mg}$ per $\mathrm{kg}$ mouse).

Some Chemical Properties of Goniopora Toxin: When the crude saline extract was adjusted to $\mathrm{pH} 2.0,7.0$, and 12.0 with $0.5 \mathrm{~N} \mathrm{HCl}$ or $0.5 \mathrm{~N} \mathrm{NaOH}$ and kept at $70^{\circ} \mathrm{C}$ for $10 \mathrm{~min}$, loss of toxicity was $100 \%$ at $\mathrm{pH} 12.0,58 \%$ at $\mathrm{pH} 7.0$, and $62 \%$ at $\mathrm{pH} 2.0$, respectively. At $4{ }^{\circ} \mathrm{C}$, toxicity remained unchanged at $\mathrm{pH} 7.0$ and $\mathrm{pH} 2.0$ for 7 days, but was lost completely at $\mathrm{pH}$ 12.0. The toxin was nondialyzable against distilled water or $0.9 \% \mathrm{NaCl}$ solution through cellophane or collodion membranes (Göttingen). From a $0.9 \% \mathrm{NaCl}$ solution it could not be extracted with 1-butanol, ethyl acetate, or diethyl ether. It was soluble in saline and acidic aqueous solutions, barely so in distilled water and insoluble in all common organic solvents. In aqueous solution, it was precipitated quantitatively by trichloroacetic acid, ammonium sulfate, and acetone.

In thin layer chromatography, the final preparation gave a single spot positive to ninhydrin and Dragendorff reagents at $\mathrm{Rf} 0.70$. It was negative to anilinediphenylamine-phosphoric acid reagent (BAILY and BOURNE, 1960; BUCHAN and SAVAGE, 1952). Toxicity to mice was detected only in the band between $\mathrm{Rf} 0.65$ and 0.75. The final preparation exhibited an absorption maximum at around $280 \mathrm{~nm}$ in 


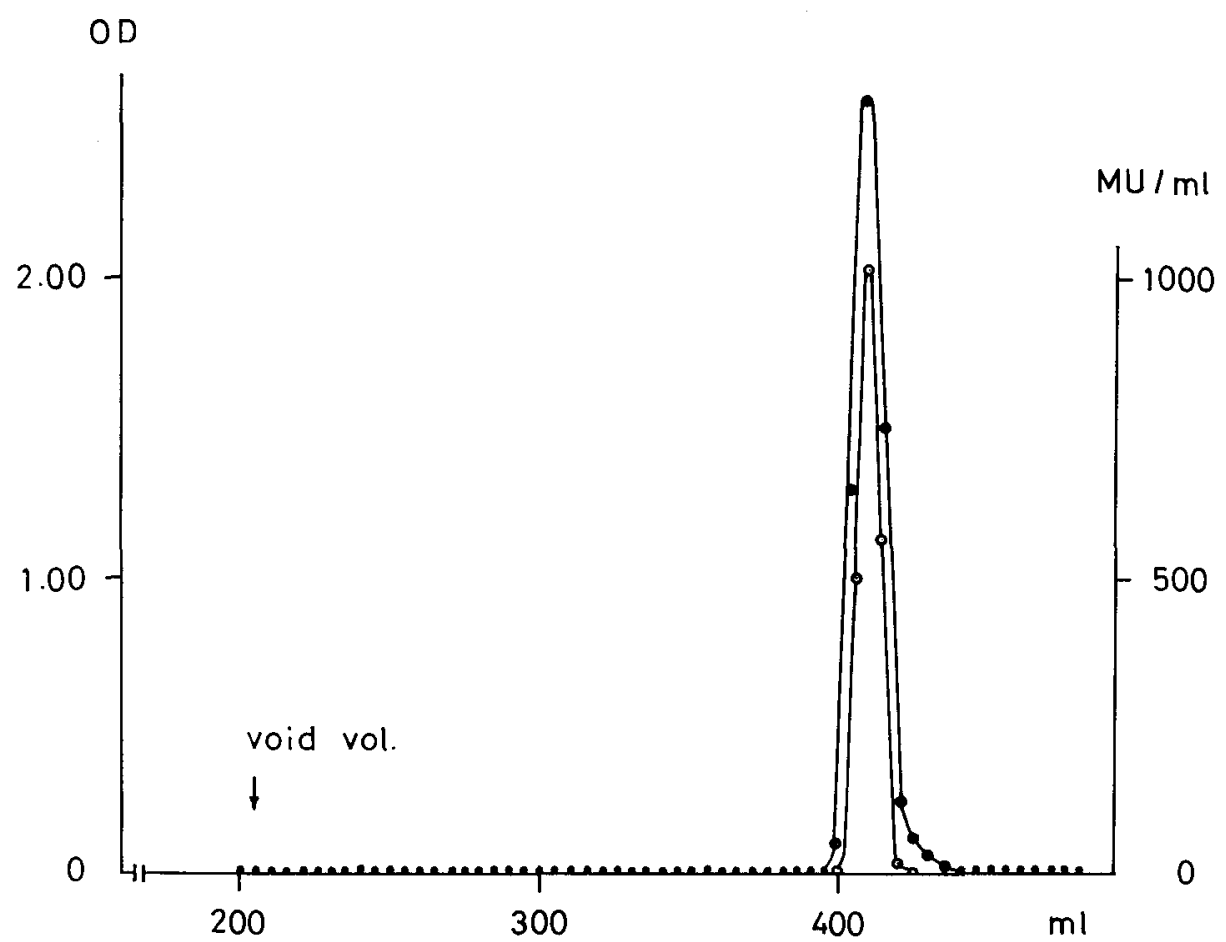

Fig. 2. Sephadex G-50 (fine) column chromatography of Goniopora toxin. $\bigcirc-\bigcirc$ Toxicity to mice;

Absorption at $280 \mathrm{~nm}$.

water and a single peak with $s_{20, w}=1.10 \mathrm{~S}$ in ultracentrifugation (Fig. 3). It was positive to Folin-Lowry (Lowry et al., 1951) and biuret reagents. The molecular weight was calculated to be 9,400 .

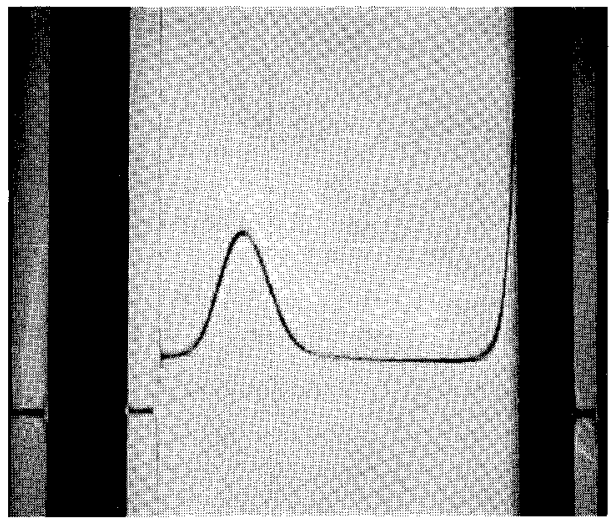

Fig. 3. U1tracentrifugation of Goniopora toxin. The most highly purified test solution was dialyzed against $0.2 \mathrm{M} \mathrm{NaCl}$ solution prior to ultracentrifugation and the retentate was centrifuged at $60,000 \mathrm{rpm}$ at $20^{\circ} \mathrm{C}$. The picture was taken $20 \mathrm{~min}$ after constant velocity was reached. 


\section{Discussion}

In the course of screening of 104 specimens of corals, water-soluble fractions of 20 specimens belonging to 8 species were found to be toxic, while all fat-soluble fractions were nontoxic. Specimens of both Goniopora sp, and Palythoa tuberculosa were found to kill mice in a short time and with characteristic symptoms. As far as our examination shows, none of the known fish toxins have been detected in these coral samples. It should be emphasized that the screening was carried out by using a hot $70 \%$ ethanolic extract in order to detect the toxins that are implicated in ciguatera intoxication. None of the toxic proteins, which might be distributed widely in corals, were detected. Goniopora toxin tolerates heating in neutral solution to some extent, which may be the reason why it was detected in the present study. In succeeding toxicity tests of Goniopora specimens and in purification of the toxin, hot $70 \%$ ethanol was replaced by cold saline as the extractant.

The Goniopora specimen from Amami-Oshima Island was tentatively identified as G. gracilis (BASSETt-SmITH) by Dr. H. Utinomi, Seto Marine Biological Laboratory, Kyoto University, and those from Shirahama as Rhodaraa tenuidens and G. planulata (EhrenberG). Our specimens were thought to include a few other species, and are therefore described in this paper as Goniopora spp. Since every specimen tested showed similar toxicity, Goniopora toxin is considered to be a common constituent in this genus. It is most likely that the toxin is contained in the nematocysts, but anatomical distribution of the toxin should await further detailed examination.

Sugryama (1955) assigned to Goniopora sp. a Japanese name, "Dokusango", which means a toxic coral, without giving any description of toxicity. KawaGuTI (1940) referred to stinging by Millepora, Goniopora and Astropora in Palau, and Halstead (1965) listed Goniopora sp. among the stinging corals. However, we could not find any specific data on the toxicity of Goniopora spp. The present study has shown that "Dokusango" is an apt designation of Goniopora spp., but we experienced no stinging sensation when we handled Goniopora spp. with our bare hands.

Judging from its chemical and pharmacological properties, Goniopora toxin seems to be different from other toxic proteins found in coelenterates. Further purification and characterization of the toxin will be reported in the near future.

\section{Summary}

Corals collected at Ishigaki Island were examined for toxicity to mice by the method used for ciguatoxic fishes. The water-soluble fractions were found to be toxic in 20 out of 104 specimens, while none of the fat-soluble fractions were toxic. Specimens of Goniopora spp. and Palythoa tuberculosa were found to be strongly toxic.

Goniopora spp. were found to contain a new toxic substance that induces characteristic symptoms in mice and possesses hemolytic activity in rabbit blood cells. 
The toxin that is lethal to mice could not be dialyzed through a cellophane membrane. It was heat-labile, but stable in neutral and acidic aqueous solutions at $4^{\circ} \mathrm{C}$. It was soluble in saline and acidic solution, barely soluble in distilled water and insoluble in all common organic solvents. It was obtained chromatographically and ultracentrifugically homogeneous by CM-cellulose and Sephadex G-50 column chromatography. The purified toxin was estimated by ultracentrifugation to have a molecular weight of 9,400 and may be a polypeptide with a toxicity of $0.5 \mathrm{mg}$ per $\mathrm{kg}$ mouse. A principle that causes hemolysis in rabbit blood cells has not yet been characterized.

\section{Acknowledgements}

The authors are grateful to Drs. H. Urinom, Seto Marine Biological Laboratory, Kyoto University and K. YamazATO, University of the Ryukyus, for their identification of the samples. Thanks are also due to Dr. P. J. ScheUER, University of Hawaii, for his kind editorial assistance with the manuscript.

\section{REFERENCES}

BaILey, R. W. and E. J. Bourne, 1960. Colour reactions given by sugars and diphenylamineaniline spray reagents on paper chromatograms. J. Chromatog., 4, 206.

Buchan, J. L. and R. I. Savage, 1952. Paper chromatography of some starch conversion products. Analyst, 77, 401.

Halstead, B. W., 1965. In: Poisonous and Venomous Marine Animals of the World, Vol. I. Washington, D. C.: U. S. Government Printing Office.

Halstead, B. W., 1967. In: Poisonous and Venomous Marine Animals of the World, Vol. II. Washington, D. C.: U. S. Government Printing Office.

Hashimoto, Y., N. Fusetani, and S. Kimura, 1969. Aluterin: a toxin of filefish, Alutera scripta, probably originating from a Zoantharian, Palythoa tuberculosa. Bull. Jap. Soc. Sci. Fish., 35, 1086.

Hashimoto, Y, and Y. Oshima, 1972. Separation of grammistins A, B and C from a soapfish Pogonoperca punctata. Toxicon, 10, 279.

Hashimoto, Y., T. Yasumoto, H. KamiYa, and T. Yoshida, 1969. Occurrence of ciguatoxin and ciguaterin in ciguatoxic fishes in the Ryukyu and Amami Island. Bull. Jap. Soc. Sci. Fish., 35, 327.

KawagutI, S., 1940. Stinging reef corals; nine note on reef corals, Note 5, Kagaku Nanyo.

Konosu, S., A. Inoue, T. Noguchi, and Y. Hashimoto, 1968. Comparison of crab toxin with saxitoxin and tetrodotoxin. Toxicon, 6, 113.

Lowry, O. H., N. J. Rosebrough, A. L. Farr, and R. J. Randall, 1951. Protein measurement with Folin-phenol reagent. J. Biol. Chem., 193, 265.

MCFarReN, E. F., 1966. Differentiation of poisons of fish, shellfish and plankton. In: Animal Toxins, p. 85, (Russell, F. E. and P. R. Saunders, Eds.). Oxford: Pergamon Press.

Schachman, H. K., 1959. Ultracentrifugation in Biochemistry, p. 181. New York: Academic Press Inc.

SugiYama, T., 1955. In: Illustrated Encyclopedia of the Fauna of Japan (UCHIDA, K., Ed.). The Hokuryukan Co. Ltd., Tokyo.

YPHANTIS, D. A., 1960. Rapid determination of molecular weights of peptides and proteins. Ann. N. Y. Acad. Sci., 88, 586. 


\section{DISCUSSION}

RandaLL (only a comment): Your work showing the high toxicity of gonioporid corals sheds some light on why this species of reef corals is rejected by Acanthaster planci. 